\title{
Dimensions of Corporate Citizenship and its Impact on Customer Loyalty An Applied Study to the Customers of the Mobile Companies in Dakahlia Governorate
}

\author{
Marwa A. M. Abdel Kader \\ Assistant Lecturer of Business Administration - Higher Institute of \\ Administrative Sciences \\ Hend S. H. Hassan, Ph.D. \\ Lecturer of Business Administration - Faculty of Commerce, Mansoura \\ University
}

Ahmed A. M. Abdel Kader, Ph.D.

Assistant Professor of Business Administration - Faculty of Commerce, Damietta University

\section{Abstract}

The objective of this applied study is to identify the impact of adopting corporate citizenship practices of Egyptian mobile service companies on the customer loyalty through a questionnaire to analyze opinions of a random sample for customers of these companies in Dakahlia Governorate. Much literature has agreed that corporate citizenship has four aspects of application: Economic citizenship, legal citizenship, ethical citizenship, and philanthropic citizenship, which were adopted in designing the conceptual framework of this study. The findings of the study indicate many points of importance, the most important of which is nullifying the main hypothesis of the study, which is "no significant impact of corporate citizenship dimensions on the customer loyalty." The findings have indicated that there is a significant independent impact of each of the four corporate citizenship dimensions on the loyalty of the mobile company customers.

Keywords: Corporate citizenship, customer loyalty, mobile companies, Egypt 


\section{Introduction}

Organizations around the world have become more motivated to practice corporate citizenship. That is because the main stakeholders of interest groups expects organizations to recognize and contribute to addressing community-related issues. Customers, employees, suppliers, shareholders/investors represent the core groups benefiting from corporate citizenship dimensions; each party has an interest in the way the organization deals with them. These groups can benefit from the organization success and can be equally affected by its mistakes. Secondary stakeholders are also important because they can act in a way that may harm or aid organizations. These include governments (especially through legislative bodies), trade unions, non-governmental organizations, activists, political activity groups and the media.

Many researches and literature have dealt with corporate citizenship topic. It can be seen from extrapolating these researches that corporate citizenship has four basic components: economic, legal, ethical, and Philanthropic (Carroll, 1991; 1998; Wood et al., 2006; Carroll, \& Buchholtz, 2015 Berry, 2010; Baumann-Pauly \& Scherer, 2013; Wang, 2014). The four dimensions of corporate citizenship are geared towards serving the community, contributing to solving its problems, and corporation assuming its responsibility for various social actors and stakeholder groups.

This study aims to identify the impact of corporate citizenship dimensions on one of the most important marketing performance aspects represented in the customer loyalty to the Egyptian communication and mobile service companies by applying to the citizens of Dakahlia Governorate. 


\section{The Exploratory Study}

To determine the study problem, an exploratory study was conducted to identify the contemporary intellectual trends in corporate citizenship and customer loyalty. This study was carried out in two phases as follows:

\section{Phase I: The Theoretical Framework and Literature}

First: The Corporate Citizenship

The literature on corporate citizenship focused on the organization/corporation as a legal person with rights, obligations and responsibilities under which the organization acts (McEachern, 2015). The corporate citizenship in itself is not limited to reforming administrative dimensions (Mirvis \& Googins, 2006; Sullivan, 2002; Pies et al., 2014). It is a comprehensive, valid and more effective strategy the organization develops to manage the risks facing its reputation. This strategy is concerned with the ethics of business and the increased complexities of the environment surrounding, which makes it imperative to exceed the corporate citizenship dimensions for it is a strategy of public relations to make it an integral part of the overall strategy of the corporation (Binz, 2017). In these researches, conceptual models of corporate citizenship were proposed, consisting of five stages of development:

- The Elementary Stage: It is characterized by lack of awareness among the organization members of the citizenship concept. Thus, the focus is on re-defining the employees' functions within the corporation, taking into account the ethical and social dimensions of the workforce, on achieving profitability as a basic economic dimension of the business organization dimensions, and on paying taxes as legal responsibility. 
- The Engagement Stage: At this stage, the organization staff is "aware", and their awareness increases, of the importance of the citizenship dimensions. At this stage, the focus is on protecting the environment and the philanthropic dimensions of the corporation.

- The Innovation Stage: The focus is on managing the relationships of stakeholder groups internally (shareholders, employees, suppliers, and distributors), and externally (customers, competitors, community members).

- The Transformation Stage: This stage is characterized by sustainability and a spirit of commitment so that the citizenship dimensions are integrated into the formal organization structure and its organizational culture.

- The Transformation Stage: At this stage, the organization has adopted the culture of corporate citizenship in all its activities, and this culture is the mainstream. The organization is also involved in coalitions and alliances with organizations of the same level that embrace the citizenship dimensions.

The researches addressing the corporate citizenship dimensions through which the relationship of corporation with stakeholder groups in the society can be identified are examined (Crane \& Matten, D. 2017; Lin, 2010, Baker et al., 2006, Baumann Pauly \& Scherer, 2013, Arnaud; Wasieleski, 2014 Berry, 2010; Papasolomou, 2017). These researches focused on explaining the dimensions and concept of corporate citizenship. These dimensions were summarized as follows:

1. The Economic Dimension: the organization to make profits to meet its economic obligations. 
2. The Legal Dimension: the corporation to abide by the applicable law, legislation and regulations.

3. The Ethical Dimension: the corporation to satisfy its ethical obligations.

4. The Philanthropic Dimension: the organization to be involve with the surrounding community in providing its various needs in a philanthropic and noncompulsory manner.

\section{Second: The Customer Loyalty}

The customer is an important asset to contemporary organizations, and organizations seek to attract and retain them as a strategic objective (Villanueva et al., 2008). The increase in customer loyalty leads to lower spending on the advertising and promotional dimensions in general, and the customer becomes a promoter of the organization and its products (Reinartz \& Kumar, 2002; Keller, 2003).

There are four variables that affect the customer loyalty to the organization and the amount (degree) of such loyalty as indicated by Kuusik (2007). These variables are: 1) Customer satisfaction, 2) Trust in the organization, 3) The organization image, 4) importance of organization's relationship with customer.

The ability to identify the factors that affect customer loyalty enables the organization to respond to customer requirements in the light of the fast-paced competition in the business environment (Nezakati et al., 2011). The study concluded that: product quality, customer comfort, trust in organization and brand are the key factor that lead to customer loyalty towards that organization. 
Most of the literature classifies the loyalty as a state of preference and purchase of a particular brand by customers; the loyalty is therefore measured by two dimensions: 1) attitudinal loyalty that is the dimension of emotion or knowledge towards a particular brand. From this perspective, the customer loyalty is the intention to repurchase in the future or commitment that reflects the knowledge and emotion associated with the customer (Bae, 2012); 2) behavioral loyalty that is the dimension of purchase frequency, which is of particular importance to managers because of their ability to measure many behavioral intentions such as repurchase or desire to buy and recommendations of others to repurchase in the future (Taplin, 2013).

The study by Mandhachitara \& Poolthong, 2011, has shown there is no relationship between corporate social responsibility and the value of company shares in the financial market, explaining that that market performance depends on financial standards and sustainability of income generation. The study discussed the roles of social responsibility and its role in building customer loyalty in the banking industry. The research concluded that there was a strong and positive relationship between social responsibility and attitudinal loyalty. There is a positive relationship between attitudes and desired consumer behavior through addressing the relationships between market orientation, corporate social responsibility and marketing performance Charpavang, 2012).

By agreeing with the above findings, each company worldwide seeks to win the customer and profit, and that they want to make the customer loyal to their product (Bagram \& Khan, 2012). The study showed that there were many factors responsible for customer loyalty, but two of them are the most 
prominent. This research study focused on how customer satisfaction and customer retention contribute to customer loyalty building. The data of this study were collected from approximately 120 students of Peshawar universities from mobile phone customers.

Based on extrapolating the literature on corporate citizenship and customer loyalty, the following points are concluded:

1. That corporate citizenship is not a new concept, but the origin of the term dates back to the early nineties of the last century, where the corporate citizenship concept was derived from another concept, the corporate social responsibility.

2. There are many elements common to the old concept (social responsibility) and the most recent concept (corporate citizenship), most notably the "economic," "legal," "ethical," and "philanthropic" dimensions.

3. The corporate citizenship has been examined by many schools of thought, including political, economic, social, administrative, and marketing - the focus of this research - and the relevant researches have proved the positive relationship between achieving desired outcomes (financial and nonfinancial) and applying some or all of the corporate citizenship dimensions, such as: economic citizenship in the form of positive financial results; legal citizenship in the form of compliance with rules, regulations and laws; ethical citizenship in the form of observing interests of different stakeholder groups such as staff, customers, suppliers, natural environment ... etc. and finally, philanthropic citizenship in the form of 
donations, care and additional efforts towards the community to obtain the status of good corporate citizen.

4. The corporate performance, positive and negative, is generally divided into financial performance and non-financial performance. The findings of the corporate citizenship literature suggest that positive and desirable financial performance is in the form of higher return on investment, increased market value, and profit-making. For example, it is closely associated with the adoption of culture and dimensions of corporate citizenship. The findings of the researches also indicate the positive relationship between corporate citizenship and positive non-financial performance of the organization in the form of marketing performance (e.g., market share, customer satisfaction, reputation, reseller relationships, product quality, sales performance, brand name, customer loyalty), or organizational performance (e.g., Efficiency and effectiveness of labor force, internal public satisfaction, human resources management, organizational loyalty).

5. Further research is needed to verify the existence and strength of the relationship between corporate citizenship and customer behavior, and to identify favorable or disruptive conditions for this relationship emergence.

6. The literature has not sufficiently addressed the customer reactions to ethical or unethical behavior from companies or corporations. They also have not investigated whether customers are more loyal to businesses that show interest in the environment or not.

7. In general, further research is needed to explore and understand the following: 
- Processes used by customers to assess the citizenship of the corporations they deal with actively.

- The extent to which these assessments are affected by the interaction between individual customer characteristics and corporate citizenship communication characteristics.

- Customers interested in corporate social responsibility tend to show high levels of market engagement.

8. Customer is an important asset for contemporary organizations, and organizations seek to attract and maintain it as a strategic objective. The increasing customer's loyalty leads to lower spending on the overall advertising and promotional dimensions, and the customer becomes a promoter of the organization and its products. It is not possible to identify only one definition of customer loyalty, not even to say that it is an interactive process (between behavior and attitude) in all cases because the result is not repeated in all cases.

9. Market orientation has an important positive relationship with corporate social responsibility. Moreover, the corporate social responsibility has a significant positive impact on marketing performance in terms of customer loyalty, financial benefits and contributions. The quality tools and statistical analysis tools (such as Six Sigma) can also be used to improve the corporate performance.

\section{Phase II: The Exploratory Study}

An exploratory study was conducted to identify the views of some mobile phone customers on the corporate citizenship 
concept. A questionnaire was created which included eight questions covering the concept, dimensions as well as loyalty of citizenship. The sample size of the exploratory study was 50 items of Mansoura University students (25 male students, 25 female students) during the second semester 2012/2013, as mobile phone users. The exploratory study data were collected from $04 / 05 / 2013$ to $17 / 05 / 2013$.

The findings of the exploratory study showed that: There is a deficiency in examining the relationship between corporate citizenship and customer loyalty by: $28 \%$ of the sample knows the corporate citizenship concept, while $68 \%$ do not, and $4 \%$ did not specify their answer. The university study represents $30 \%$ of the sources the sample obtains its information on corporate citizenship, the media represents $12 \%$, while there is $22 \%$ of the sample did not specify choices, there are 36\% distributed among self-sources, knowledge from relatives and friends, and all these sources. $14 \%$ of the sample says that corporate citizenship programs are not widespread at all among organizations in general, $56 \%$ believes they are not widespread, $24 \%$ is of the opinion that they are fairly widespread, $4 \%$ widespread enough, and $2 \%$ quite widespread. $88 \%$ reported that they did not care when deciding to deal with the mobile company in its efforts in the corporate citizenship, $8 \%$ took this into consideration, while $4 \%$ did not specify a choice.

\section{The Research Gap}

Based on extrapolating the literature and the findings of the exploratory study, it is clear that there is lack of studies that dealt with the relationship between corporate citizenship and customer loyalty, in particular, in foreign studies, applied studies in the Arab world and the Egyptian context, in particular. This 
research gap requires examining the relationship between corporate citizenship and customer loyalty. This study therefore aims at providing useful contribution of scientific, marketing and community value by examining the relationship between the adoption of corporate and community citizenship for Egyptian mobile phone companies and the positive non-financial performance of these companies in the form of market performance represented in the customer loyalty.

Thus, the study problem can be framed in the following question: What is the relationship nature between the dimensions of corporate citizenship and customer loyalty?

This question can be translated into several sub-questions as follows:

- Is there a difference between the opinions of mobile company customers (when demographic factors are different) on the dimensions of corporate citizenship?

- Is there a difference between the opinions of mobile company customers (when demographic factors are different) on the customer loyalty?

- What is the impact of corporate citizenship dimensions on customer loyalty?

In light of the study problem, the main objectives are:

1. To examine the different dimensions of corporate citizenship when demographic factors are different.

2. To examine the difference in the loyalty of mobile company customers when demographic factors are different.

3. To identify the impact of corporate citizenship dimensions on customer loyalty. 
Based on the objectives of the study, the proposed model of the study can be illustrated as follows:

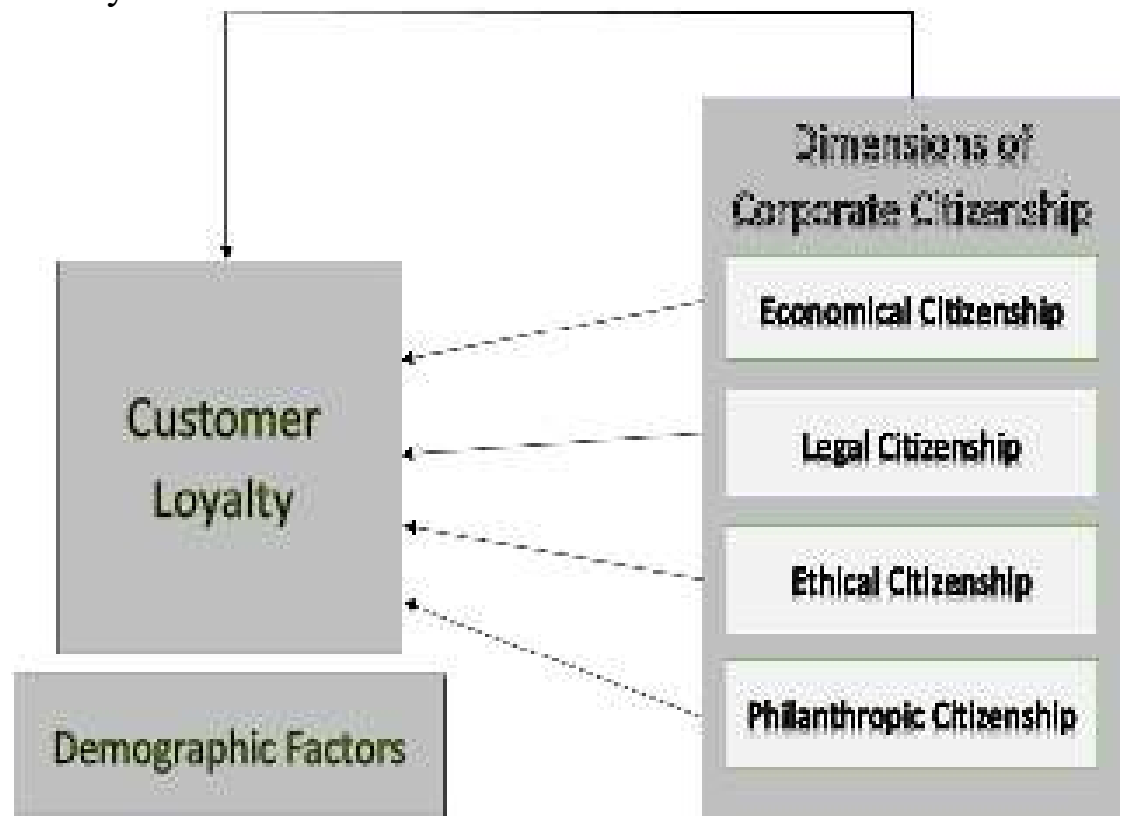

Figure (1) Impact of Corporate Citizenship on Customer Loyalty - A Conceptual Model

Based on the problem addressed in this study, and in the light of the proposed model, the study hypotheses were formulated as follows:

The First Hypothesis: There would be no significant difference between the opinions of mobile service customers on the corporate citizenship dimensions according to the demographic variables.

The Second Hypothesis: There would be no significant difference between the opinions of mobile service customers on the customer loyalty according to the demographic variables. 
The Third Hypothesis: There would be no significant relationship between the corporate citizenship dimensions and customer loyalty.

The Fourth Hypothesis: There would be no significant impact of corporate citizenship dimensions on customer loyalty.

\section{The Methodology}

The study used the analytical (deductive) method which is concerned with extracting the results from the populations under study. This means using the data collected to reach a decision on the hypotheses or the set of initial hypotheses that were developed to explain the phenomenon. This decision is made either by rejecting or accepting the hypothesis or the data is insufficient.

\section{First: Population and Sample}

The population of the study consists of mobile phone service customers in Dakahlia Governorate due to the large number of customers and their geographical spread in different areas. The survey list was posted on the Internet using the Google Forms application, as well as on the social network. The list was open for a week where the size of responses was 381 items. The statistical analysis was conducted on them. During the analysis process, there were three errors in the total items, the number of actual items were 378. The survey of research items was conducted using the Online Survey.

\section{Second: The Tool}

A specially designed survey list was used to collect data from the study items. The measures used to prepare the survey list consisted of 24 statements to measure the dimensions of corporate citizenship, and 19 statements to measure customer loyalty. 


\section{Third: The Validity and Reliability Tests}

After completing the initial design of the survey list, the validity and reliability tests of this list were carried out by conducting descriptive validity tests to ensure that the measures used are closely related to what is to be measured and that the research tool has theoretically covered all variables to be met. That was checked by relying on the views of some business administration professors. The survey in its initial design was presented to some customers of the mobile phone service companies, and accordingly the wording of some statements were modified new statements were added. To measure the reliability of the survey lists as a data collection tool, Cronbach's alpha coefficient was used to examine the reliability of the field study results when generalizing the results. Table (1) shows the reliability results of the list of mobile phone company customers under question using the alpha reliability coefficient.

Table (1): Results of Testing Validity and Reliability of Study Variables

\begin{tabular}{cccc}
\hline \multirow{2}{*}{ Section } & Dimensions & $\begin{array}{c}\text { Reliability } \\
\text { Coefficient } \\
\text { (Alpha) }\end{array}$ & $\begin{array}{c}\text { Validity } \\
\text { Coefficient }\end{array}$ \\
\hline \multirow{2}{*}{$\begin{array}{c}\text { First: Corporate } \\
\text { Citizenship }\end{array}$} & Economic & 0.847 & 0,92 \\
\cline { 2 - 4 } & Legal & 0.716 & 0.85 \\
\cline { 2 - 4 } & Ethical & 0.852 & 0.92 \\
\hline $\begin{array}{c}\text { Second: The Customer } \\
\text { Loyalty }\end{array}$ & & 0.882 & 0.94 \\
\hline
\end{tabular}

The table showed that values range from 0.716 as a minimum of legal dimension, 0.946 as a maximum of customer loyalty. Cronbach's alpha coefficient of the measure as a whole was 0.97. This indicates a high degree of reliability as a measure of study. 


\section{The Analysis of Data and Discussion of Results}

To achieve the objectives of the study and to analyze the data collected, many statistical methods were used, such as KruskalWallis, Mann Whitney, Pearson's linear correlation coefficient, and the multiple linear regression model. The results were as follows:

The First Hypothesis: There would be no significant difference between the opinions of mobile service customers on the corporate citizenship dimensions according to the demographic variables (name of organization, duration of the customer's relationship with organization, age of customer, type of customer, income level, level of education, place of residence). Kruskal-Wallis, Mann Whitney analyses were conducted and the results were as follows:

Table (2) Difference between Customers' Opinions on Corporate Citizenship Dimensions According to Demographic Variables

\begin{tabular}{cccc}
\hline Variable & $\chi^{2}$ & Sig & Significance \\
\hline $\begin{array}{c}\text { Name of Organization } \\
\text { Duration of Dealing with } \\
\text { Organization }\end{array}$ & 4.329 & 0.115 & Insignificant \\
\hline Age & 0.334 & 0.846 & Insignificant \\
\hline Gender & 2.450 & 0.294 & Insignificant \\
\hline Income Level & -1.371 & 0.170 & Insignificant \\
\hline Educational Level & 0.565 & 0.754 & Insignificant \\
\hline Residence & 7.279 & 0.026 & Significant \\
\hline
\end{tabular}

Source: From the results of statistical analysis, significance $=0.05$

The above table shows that there is no significant difference between the opinions of the mobile companies service customers in Dakahlia Governorate on the corporate citizenship dimensions (economic, legal, ethical, philanthropic) according to organization name, duration of customer's relationship with organization, customer age, type of customer, level of 
customer's income, place of residence. On the other hand, there is a significant difference between the opinions of customers on the corporate citizenship dimensions according to the level of customer's education.

We conclude from the above results that all customers have the same concerns to meet their demands of service in terms of network quality, adherence to the laws set by the government, adherence to the work carried out in a fair and transparent manner, and in terms of providing advanced services, continuous renewal in these services, continuous follow-up system, in addition to service dimension compliance with legal systems. Customers are also looking for nondiscrimination and credibility of the services provided, as well as taking into account ethics in dealing and services provided, paying attention to campaigns to promote cultural and sports dimensions, non-discrimination among them due to age, gender or geographical location. Customers want to be provided with high quality services, and that these organizations add wealth and value to the economy for benefiting them again, as well as

achieve a certain amount of welfare in services, attention to fair behavior in the market, keep away from monopoly, and protect workers' rights. All these are not different from one governorate to another. As for the level of customer's education as a demographic variable, there is a significant difference between the opinions of customers on the corporate citizenship dimensions that the higher the level of education is, the more attention to the corporate citizenship aspects.

The Second Hypothesis: There would be no significant difference between the opinions of mobile service customers on the customer loyalty according to the demographic variables (name of organization, duration of customer's relationship with 
organization, age of customer, type of customer, income level, level of education, place of residence). Kruskal-Wallis, Mann Whitney analyses were conducted and the results were as follows:

Table (3) Difference between Customers' Opinions on Corporate Customer Loyalty According to Demographic

\begin{tabular}{|c|c|c|c|}
\hline Variable & $\chi^{2}$ & Sig & Significance \\
\hline Name of Organization & 7.755 & 0.021 & Significant \\
\hline $\begin{array}{c}\text { Duration of Dealing with } \\
\text { Organization }\end{array}$ & 0.155 & 0.926 & Insignificant \\
\hline Age & 1.689 & 0.430 & Insignificant \\
\hline Type & -1.187 & 0.235 & Insignificant \\
\hline Income Level & 1.578 & 0.454 & Insignificant \\
\hline Educational Level & 4.685 & 0.096 & Insignificant \\
\hline Residence & 0.193 & 0.660 & Insignificant \\
\hline
\end{tabular}

Source: From the results of statistical analysis, significance $=0.05$

The previous table shows that there is a significant difference between the opinions of mobile company customers in Dakahlia Governorate on the customer loyalty according to the organization name only. As for the other demographic factors, there was no significant difference between customers' opinions on customer loyalty according to customer's relationship duration with the organization, age of customer, type of customer, customer's level of income, customer's level of education, and place of residence.

The above results indicate that the customer is one of the important assets to contemporary organizations, and organizations seek to attract and retain them as a strategic objective. In general, customer loyalty to the organization depends on various considerations, including all services provided by the organization to be satisfactory, attention paid to complaints, follow-up, quick response, emotional link, and 
understanding of potential differences. These services vary from one company to another. Customer loyalty also depends on the service quality, continuous renewal of service commensurate with the needs of the customer according to the age level. The customer is also willing to stick to the organization despite price fluctuations.

The Third Hypothesis: There would be no significant relationship between the corporate citizenship dimensions and customer loyalty. Pearson's linear correlation coefficient was used to test the hypothesis and the results were as follows:

Table (4) Pearson's Correlation Coefficients of Study Variables

\begin{tabular}{ccccccc}
\hline & $\begin{array}{c}\text { Econo } \\
\text { mic }\end{array}$ & $\begin{array}{c}\text { Leg } \\
\text { al }\end{array}$ & $\begin{array}{c}\text { Ethic } \\
\text { al }\end{array}$ & $\begin{array}{c}\text { Philanthro } \\
\text { pic }\end{array}$ & $\begin{array}{c}\text { Corpora } \\
\text { te } \\
\text { Citizens } \\
\text { hip }\end{array}$ & $\begin{array}{c}\text { Custom } \\
\text { er } \\
\text { Loyalty }\end{array}$ \\
\hline Economic & 1 & $\begin{array}{c}0.71 \\
6\end{array}$ & 0.74 & 0.58 & 0.856 & 0.726 \\
\hline Legal & 0.716 & 1 & 0.726 & 0.562 & 0.798 & 0.669 \\
\hline Ethical & 0.74 & $\begin{array}{c}0.72 \\
6\end{array}$ & 1 & 0.54 & 0.84 & 0.728 \\
\hline $\begin{array}{c}\text { Philanthro } \\
\text { pic }\end{array}$ & 0.58 & 0.56 & 0.54 & 1 & 0.76 & 0.66 \\
\hline $\begin{array}{c}\text { Corporate } \\
\text { Citizenshi } \\
\text { p }\end{array}$ & 0.856 & $\begin{array}{c}0.79 \\
8\end{array}$ & 0.84 & 0.76 & 1 & 0.95 \\
\hline $\begin{array}{c}\text { Customer } \\
\text { Loyalty }\end{array}$ & 0.726 & 0.66 & 0.728 & 0.66 & 0.95 & 1 \\
\hline
\end{tabular}

Source: From the results of statistical analysis, significance $=0.05$

We note from the previous table that there is a significant correlation between economic citizenship and customer loyalty with a correlation coefficient 0.73 . The significant ethical 

coefficient 0.67 . The ethical citizenship reached a significant correlation coefficient 0.73 , customer loyalty and philanthropic citizenship 0.66. All of them are with a direct correlation coefficient. Thus, the strongest relationship with the customer loyalty is the ethical dimension followed by economic and philanthropic in the same rank. The least is the legal.

From the above, it is clear that there is a significant correlation between each dimension of corporate citizenship and customer loyalty, which means that the higher the level of the corporate citizenship sense through daily practice is, the greater the customer loyalty is for these services in Dakahlia Governorate. This means rejecting the third hypothesis.

The Fourth Hypothesis: There would be no significant impact of corporate citizenship dimensions on customer loyalty. The multiple linear regression was used to analyze the study data and test the hypothesis. The results were as follows:

Table (5) Impact of Corporate Citizenship Dimensions on Customer Loyalty

\begin{tabular}{cccccccc}
\hline Variables & $\mathbf{B}$ & $\begin{array}{c}\text { Beta } \\
\boldsymbol{\beta}\end{array}$ & $\mathbf{T}$ & $\mathbf{S i g}$ & $\begin{array}{c}\text { Coefficient of } \\
\text { Determination } \\
\boldsymbol{R}^{\mathbf{2}}\end{array}$ & $\mathbf{F}$ & (Sig) \\
\cline { 1 - 5 } Constant & - & & - & & & & \\
\hline Economic & .270 & - & 1.117 & .265 & & & \\
\hline Legal & .104 & .093 & 1.948 & .052 & .671 & 189.847 & $(.000)$ \\
\hline Ethical & .306 & .309 & 6.310 & .000 \\
\hline Philanthropic & .282 & .291 & 7.673 & .000 & & & \\
\hline Source: From the results of statistical analysis, significance $=\mathbf{0 . 0 5}$ &
\end{tabular}

The table shows that there is a significant impact of corporate citizenship dimensions (economic, legal, ethical, philanthropic) on the customer loyalty where $\beta$ values ranged between .093 as the lowest value and .309 as the highest value. The significance was either equal to or below the significance level $5 \%$. T value 

corporate citizenship dimensions (economic, legal, ethical, philanthropic) collectively $67.1 \%$ are interpreted from the change occurred in the customer loyalty where the coefficient of determination value was $\left(\mathrm{R}^{2}=0.671\right)$. That means that $32.9 \%$ of the change in customer loyalty is explained by other variables not included in the current regression model, and some random errors resulting from the inaccuracy of the results.

\section{Recommendations}

As the study indicates that there is no significant difference between the opinions of the mobile service company customers on the corporate citizenship dimensions, it recommends increasing the attention continuously to reach different segments of the community, raising awareness about corporate citizenship and its dimensions, and dimensions that serve the community provided by the mobile companies. It also recommends that mobile companies expand the corporate citizenship dimensions to overcome the claims that these organizations face describing some of their activities as environmental damage, harm to the health of citizens for profit. This also contributes to improving the image of these organizations, and contributes to building customer loyalty. It is also necessary for these organizations to adopt - within the framework of corporate citizenship - the philosophy of building strong and profitable relationships with customers. This philosophy is the main purpose that these organizations should seek.

As the study has found that there is a significant difference between the opinions of the mobile service company customers according to their educational levels, these organizations are supposed to adopt multiple strategies that are not stereotyped to address the different levels of education. The study also recommends the need for organizations to adopt strategies that fit different customer segments and contribute to 
building loyalty such as what has been called Listening Posts. This recommendation is made in the light of what highlighted by the field study that there was a significant difference between the opinions of customers on the customer loyalty depending on the company they deal with. As there is a significant impact of corporate citizenship dimensions on customer loyalty, the study recommends building comprehensive promotional strategies that

seek to educate the clientele on the dimensions of these organizations for corporate citizenship. It emphasizes the nature of the correlation between these dimensions and loyalty behavior by the client towards the organization and its services. It is expected that this strategy will include many aspects related to holding seminars and lectures to educate the clientele, as well as brochures and publications that contribute to this regard. These organizations can also invest the potential of social sites and accounts of modern communications in this regard.

The study recommends that organizations adopt other applied approaches to corporate citizenship that are not limited to the four dimensions. Rather, it may be appropriate to adopt the views of their internal clientele, which deal with other branching of these dimensions, such as economic responsibility towards owners, philanthropic responsibility towards employees, and philanthropic responsibility towards the natural environment. It is also important that organizations should follow new standards to measure customer loyalty that can accurately reflect the loyalty behavior in its multiple dimensions in the light of loyalty programs, which have become widely used in various organizations. They rely, in essence, on collecting and recording extensive information about these customers.

On future studies, the study recommends the continuation of scientific research efforts in this field (with its two elements represented in corporate citizenship dimensions and customer loyalty), through research topics such as The impact of marketing 
ethical dimensions on customer loyalty through the dimensions of different corporations in the components of the marketing mix in its traditional form known (4P's), as in the dimensions of green marketing, the dimensions of digital marketing and others. Among the proposed research ideas is to examine selling strategies of mobile companies in the light of corporate citizenship dimensions and its reflection on customer loyalty, and to study the impact of corporate citizenship initiatives of Egyptian organizations on their competitive advantages by mediating variables of customer satisfaction, corporate reputation, and planning of corporate citizenship programs in private sector enterprises.

\section{References}

Arnaud, S. \& Wasieleski, D. (2014), "Corporate Humanistic Responsibility: Social Performance through Managerial Discretion of the HRM", Journal of Business Ethics, Vol. 120, pp. 313-334.

Bae, Y. (2012), "Three Essays on the Customer SatisfactionCustomer Loyalty Association", PhD Dissertation, University of Iowa, http://ir.uiowa.edu/cgi/viewcontent.cgi?article=3256\&co ntext=etd (accessed: Sep. 2017).

Bagram M., \& Khan, S. (2012), “Attaining Customer Loyalty: The Role of Consumer Attitude and Customer Behavior", International review of management and business research, Vol. 1, No. 1, pp: 1-8.

Baker, T. L., T. G. Hunt and M. C. Andrews (2006), "Promoting Ethical Behavior and Organizational Citizenship Behaviors: The Influence of Corporate Ethical Values", Journal of Business Research 59 (7), 849-857. 
Baumann-Pauly, D. \& Scherer, A. (2013), "The Organizational Implementation of Corporate Citizenship: An Assessment Tool and Its Application at UN Global Compact Participants", Journal of Business Ethics, Vol. 117, pp. 1-17.

Berry, G. (2010), “Improving Organizational Decision-Making: Reframing Social, Moral, And Political Stakeholders Concerns", The Journal of Corporate Citizenship, Vol. 38, pp. 33-48.

Binz, C. A., Ferguson, K. E., Pieper, T. M., \& Astrachan, J. H. (2017). Family business goals, corporate citizenship behaviour and firm performance: disentangling the connections. International Journal of Management and Enterprise Development, 16(1-2), 34-56.

Carroll, A. (1991), "The Pyramid of Corporate Social Responsibility: Toward the Moral Management of Organizational Stakeholders", Business Horizons, July/August, p. 42.

Carroll, A. (1998), "The Four Faces of Corporate Citizenship", Business and Society Review, Vol. 100, pp. 1-7.

Carroll, A. B., \& Buchholtz, A. K. (2015). Corporate citizenship: social responsibility, responsiveness, and performance. Classics of Organization Theory, 439.

Charpavang, C. (2012) "The Relationship among Market Orientation, Corporate Social Responsibility, and Marketing Performance in Thailand Manufacturing", International Journal of Business Strategy, Vol. 12, No. 4, pp. 36-61.

Crane, A., \& Matten, D. (2017). Unleashing the Monster of 'New Corporate Citizenship Theory'to Confront Category 
Crisis1. Business, Capitalism and Corporate Citizenship: A Collection of Seminal Essays.

Keller, K. (2003), "Strategic Brand Management: Building, Measuring, And Managing Brand Equity", $2^{\text {nd }} E d$, Prentice Hall, Upper Saddle River, NJ.

Kuusik, A. (2007), “Affecting Customer Loyalty: Do Different Factors Have Various Influences in Different Loyalty Levels?" University of Tartu Faculty of Economics and Business Administration, http://core.ac.uk/download/pdf/6609547.pdf (accessed: Sep. 2017).

Lin, C. (2010), "Modeling Corporate Citizenship, Organizational Trust, and Work Engagement Based on Attachment Theory", Journal of Business Ethics, Vol. 94, No. 4, pp. 517-531.

Mandhachitara R, \& Poolthong Y. (2011), “A Model of Customer Loyalty and Corporate Social Responsibility", The Journal of Services Marketing, Vol. 25, pp. 122-133.

McEachern, M. G. (2015). Corporate citizenship and its impact upon consumer moralisation, decision-making and choice. Journal of Marketing Management, 31(3-4), 430-452.

Mirvis, P., Googins, B. (2006), "Stages of Corporate Citizenship: A Developmental Framework", Boston Center for Corporate Citizenship at Boston College Monograph.

Nezakati, H., Kuan, Y. \& Asgari, O. (2011), "Factors Influencing Customer Loyalty Towards Fast Food Restaurants", International Conference on Sociality and Economics Development, IACSIT Press, Singapore, https://www.academia.edu/3613490/Factors influencing c ustomer loyalty towards fast food restaurants

Papasolomou, I. (2017). The Practice of Internal Corporate Social Responsibility in SMEs in Cyprus. In Corporate Social 

Cham.

Pies, I., Beckmann, M., \& Hielscher, S. (2014). The political role of the business firm: An ordonomic concept of corporate citizenship developed in comparison with the Aristotelian idea of individual citizenship. Business \& Society, 53(2), 226-259.

Reinartz, W. \& Kumar, V. (2002), "The Mismanagement of Customer Loyalty", Harvard Business Review, Vol. 80, July, pp. 86-94.

Sullivan, R. (2002). "Enron: One Step Forward or Two Steps Back for Effective Self-Regulation?" The Journal of Corporate Citizenship. No. 8, pp. 91-104.

Taplin, R. (2013), "The influence of competition on visitor satisfaction and loyalty", Tourism Management, Vol. 36, pp. 238-46.

Villanueva, J., Yoo, S., \& Hanssens, D. (2008), "The Impact of Marketing-induced vs. Word-of-mouth Customer Acquisition on Customer Equity Growth", Journal of Marketing Research, Vol. 45, pp. 48-59.

Wang, C. (2014), "Do Ethical and Sustainable Practices Matter?", International Journal of Contemporary Hospitality Management, Vol. 26, No. 6, pp. 930-947.

Wood, D., Logsdon, P., Lewellyn G. \& Davenport, K. (2006), "Global Business Citizenship: A Transformative Framework for Ethics and Sustainable Capitalism" (M.E. Sharpe, Armonk, NY/London, England). 
